(c) American Dairy Science Association, 2004.

\title{
Effects of Corn Processing on Growth Characteristics, Rumen Development, and Rumen Parameters in Neonatal Dairy Calves
}

\author{
K. E. Lesmeister and A. J. Heinrichs \\ Department of Dairy and Animal Science, \\ The Pennsylvania State University, University Park 16802
}

\begin{abstract}
Neonatal Holstein calves were fed texturized calf starters containing 33\% whole (WC), dry-rolled (DRC), roasted-rolled (RC), or steam-flaked (SFC) corn to investigate how corn processing method affects intake, growth, rumen and blood metabolites, and rumen development. In the first experiment, 92 Holstein calves (52 male and 40 female) were started at $2 \pm 1 \mathrm{~d}$ of age and studied for $42 \mathrm{~d}$. Starter dry matter (DM) intake was measured and fecal scoring conducted daily. Growth and blood parameter measurements were conducted weekly. A subset of 12 male calves (3/treatment) was euthanized at $4 \mathrm{wk}$ of age and rumen tissue sampled for rumen epithelial development measurements. Experiment 2 consisted of 12 male Holstein calves ruminally cannulated at $7 \pm 1 \mathrm{~d}$ of age. Rumen fluid and blood samples were collected during wk 2 to 6 . In the first experiment, postweaning and overall starter and total DM intake were significantly higher in calves fed starter with DRC than RC or SFC. Postweaning and overall starter and total DM intake were significantly higher in calves fed starter with WC than SFC. Postweaning average daily gain was significantly greater in calves fed starter with DRC than SFC. Blood volatile fatty acid concentrations were significantly higher in calves fed starter with SFC than in calves fed all other treatments. Papillae length and rumen wall thickness at $4 \mathrm{wk}$ were significantly greater in calves fed starter with SFC than DRC and WC, respectively. In experiment 2, calves fed starter with WC had higher rumen $\mathrm{pH}$ and lower rumen volatile fatty acid concentrations than calves fed all other starters. Rumen propionate production was increased in calves receiving starter with SFC; however, rumen butyrate production was higher in calves fed starter with RC. Results indicate that the type of processed corn incorporated into calf starter can influence intake, growth, and rumen parameters in neonatal calves. Calves consuming starter con-
\end{abstract}

Received February 6, 2004.

Accepted June 29, 2004.

Corresponding author: A. J. Heinrichs; e-mail: ajh@psu.edu. taining RC had similar body weight, feed efficiency, and rumen development but increased structural growth and ruminal butyrate production when compared with the other corn processing treatments.

(Key words: corn processing, neonatal dairy calves, Holstein)

Abbreviation key: $\mathbf{A D G}=$ average daily gain, $\mathbf{D R C}=$ dry-rolled corn, $\mathbf{D S}$ = days scoured, $\mathbf{F E}$ = feed efficiency, HEM = blood hematocrit, $\mathbf{H G}=$ heart girth, $\mathbf{H H}=$ hip height, $\mathbf{H W}=$ hip width, $\mathbf{P L}=$ papillae length, $\mathbf{P T P}=$ plasma total protein, $\mathbf{P W}=$ papillae width, $\mathbf{R C}=$ roasted-rolled corn, RWT = rumen wall thickness, $\mathbf{S F C}=$ steam-flaked corn, $\mathbf{W C}=$ whole corn, $\mathbf{W H}=$ withers height.

\section{INTRODUCTION}

Mechanical and chemical alterations during processing increase surface area exposure and improve ruminal, intestinal, and total tract starch digestibility of seed grains (Huntington, 1997; Owens et al., 1997). Starch availability, and therefore digestibility, typically is highest in steam-flaked grains, followed by finely-ground, then dry-rolled grains, and is lowest in whole grains (Theurer, 1986; Huntington, 1997; Crocker et al., 1998). However, some researchers have reported no differences in starch digestibility between steam-processed and dry-rolled corn (DRC) (Joy et al., 1997; Reis and Combs, 2000). In addition, higher levels of grain processing negatively influence dietary fiber digestibility (Joy et al., 1997; Crocker et al., 1998).

Previous studies indicated that grain processing level influenced rumen VFA production, rumen $\mathrm{pH}$, and rumen $\mathrm{NH}_{3}$. Murphy et al. (1994) reported increased total VFA concentrations and decreased ruminal $\mathrm{pH}$ when whole corn (WC) was replaced with DRC in all-concentrate diets. However, grain processing had less influence on total VFA production and rumen $\mathrm{pH}$ when forages were incorporated into the ration (Joy et al., 1997; Crocker et al., 1998). Heat processing of grains has been shown to increase ruminal propionate production (Joy et al., 1997; Crocker et al., 1998), whereas ruminal butyrate production appears to be enhanced by physical 
processing (Murphy et al., 1994). Some researchers have indicated that increased grain processing lowers rumen $\mathrm{NH}_{3}$ (Crocker et al., 1998); however, this is not always the case (Joy et al., 1997).

Different methods and extent of grain processing also have been reported to influence DMI. Highest intakes have been observed in diets containing dry-rolled grains, followed by whole, steam-rolled, and steamflaked grains, with finely ground grains resulting in the lowest intake (Owens et al., 1997). However, diet composition and/or forage level has been shown to alter or diminish grain processing effects on intake (Chen et al., 1994). Feeding whole, dry-rolled, or steam-rolled corn resulted in similar rates of gain in beef steers (Theurer, 1986; Owens et al., 1997). Feeding raw roasted, or conglomerated sorghum grain to calves resulted in no effects on calf performance or rumen and blood metabolites (Abdelgadir and Morrill, 1995). However, similar average daily gain (ADG), coupled with decreased DMI, indicates an enhancement in feed efficiency $(\mathbf{F E})$ when grains are heat processed (Schuh et al., 1970; Owens et al., 1997).

In the preweaned dairy calf, solid food intake, especially concentrate or high carbohydrate diets, stimulates rumen microbial proliferation and VFA production, subsequently initiating rumen development (Harrison et al., 1960). Therefore, alterations in DMI due to differences in grain processing may influence the rate and extent of rumen development. Butyrate and, to a lesser extent, propionate are used as energy sources by the rumen epithelium and subsequently have the greatest influence on epithelial development (Tamate et al., 1962). Grain processing level and the concomitant effect on VFA production may therefore influence rumen development. Furthermore, increased starch digestibility, resulting from processing, may be advantageous in neonatal calf growth. Conversely, a possible negative relationship between processing level and rumen $\mathrm{pH}$ may decrease rumen development or epithelial absorptive ability (Bull et al., 1965). However, the effects of corn processing level on calf growth and rumen development have not been elucidated. Most corn processing studies have been conducted utilizing mature ruminants, and extrapolation of these results to immature ruminants may be limited due to known differences in digestion kinetics, microbial populations, and rumen capacity (Vazquez-Anon et al., 1993). Therefore, this study was conducted to determine the effects of corn processing method on intake, growth characteristics, rumen development, and rumen parameters in neonatal calves.

\section{MATERIALS AND METHODS Animals, Housing, and Diets}

Texturized calf starters containing 33\% WC (density $=0.72 \mathrm{~kg} / \mathrm{L}), \mathrm{DRC}(0.76 \mathrm{~kg} / \mathrm{L})$, roasted-rolled $(\mathbf{R C})$
$(0.43 \mathrm{~kg} / \mathrm{L})$, or steam-flaked (SFC) $(0.39 \mathrm{~kg} / \mathrm{L})$ corn $(\mathrm{DM}$ basis) were fed to 92 Holstein calves. Roasted-rolled corn was roasted at $131^{\circ} \mathrm{C}$ for $90 \mathrm{~s}$, hot water conditioned for $15 \mathrm{~min}$, coarse rolled while still warm, then air cooled for 15 to $20 \mathrm{~min}$. Steam-flaked corn was processed according to the procedure described by Theurer et al. (1999). Calves (52 male and 40 female) were separated from their dams shortly after birth, randomly assigned by sex to treatment, blocked by birth date (23 blocks/treatment), and placed on experiment at $2 \pm 1 \mathrm{~d}$ of age. Abrupt weaning occurred at $28 \pm 1 \mathrm{~d}$ of age, with calves maintained on the study until $42 \pm 1 \mathrm{~d}$ of age. Calves were housed in a naturally and mechanically ventilated barn in $1.2-\times 2.4-\mathrm{m}$ individual pens bedded with wood shavings. Nose to nose contact between calves was minimized by pen arrangement. All calves received $4 \mathrm{~L}$ of colostrum within $12 \mathrm{~h}$ of birth, followed by 4 feedings of colostrum. Calves received a $20 \% \mathrm{CP}$, $20 \%$ fat, nonmedicated milk replacer containing allmilk protein (Land O' Lakes Animal Milk Products Co., Arden Hills, MN) from $3 \mathrm{~d}$ of age until weaning. Milk replacer was provided in 2 equal feedings per day at $10 \%$ of birthweight mixed at $12.5 \% \mathrm{DM}(\mathrm{ME}=4.75$ Mcal/kg; NRC, 2001) until abrupt weaning. Texturized calf starter was offered ad libitum, and intake was measured daily, beginning when calves were placed on the study. Water was provided free of choice and changed twice daily.

\section{Starter Nutrient Composition and Particle Size}

Starter samples were analyzed in duplicate for moisture (AOAC, 1990). Crude protein was analyzed using a Leco FP-528 Nitrogen Combustion Analyzer (Leco, St. Joseph, MI) with soluble crude protein determined as described by Krishnamoorthy et al. (1982), where insoluble protein was recovered on 7-cm diameter filter paper and introduced into a Leco FP-528 Nitrogen Combustion Analyzer for determination of crude protein. Values for total digestible nutrients, net energy of maintenance, and net energy of gain were calculated using the NRC (2001) model. Starter samples were analyzed for NDF, ADF, and crude fat (AOAC, 1990) using a Tecator Soxtec System HT 1043 extraction unit (Tecator, Foss NA, Eden Prairie, MN). Ash and mineral content were determined (AOAC, 1990) utilizing a Perkin Elmer 3300 XL ICP (Perkin Elmer, Shelton, CT). Starch and sugar content were determined according to Holm et al. (1986) and Dubois et al. (1956), respectively. Values for nonstructural carbohydrates were calculated by the addition of starch and sugar content. Particle size distribution was determined utilizing an Analysette 3 PRO Vibratory Sieve Shaker (Fritsch, Oberstein, Germany). Approximately $330 \mathrm{~g}$ (DM) of starter were 
placed on a series of stacked sieves arranged in descending order and shaken for 2 min at an amplitude of $0.7 \mathrm{~mm}$. Following separation, retained particles were weighed to determine the amount and percentage of $\mathrm{DM}$ retained on each sieve.

\section{Fecal Scoring, Health Monitoring, and Experimental Measurements}

Fecal scoring for determination of fecal fluidity, consistency, odor, and days scoured (DS) was conducted utilizing the procedure of Larson et al. (1977). Scoring was as follows: for fecal fluidity, $1=$ normal, $2=$ soft, 3 = runny, or $4=$ watery; for fecal consistency, $1=$ normal, $2=$ foamy, $3=$ mucous, $4=$ sticky, or $5=$ consti pated; for fecal odor, 1 = normal, 2 = slightly offensive, or $3=$ highly offensive. A scour day was recorded if fecal fluidity $=3$ or 4 , fecal consistency $=3$, and fecal odor $=$ 2 or 3. During this study, an additional procedure (Heinrichs et al., 2003) for monitoring calf health was used. Scoring for the new procedure was as follows: for scour scoring, $1=$ normal, $2=$ soft to loose, $3=$ loose to watery, $4=$ watery, mucous, slightly bloody, $5=$ watery, mucous, and bloody; for respiratory scoring, 1 = normal, $2=$ slight cough, $3=$ moderate cough, $4=$ moderate to severe cough, 5 = severe and chronic cough; and for general appearance scoring, $1=$ normal and alert, $2=$ ears drooped, $3=$ head and ears drooped, dull eyes, slightly lethargic, $4=$ head and ears drooped, dull eyes, lethargic, $5=$ severely lethargic. For the new calf monitoring procedure, a scour day was considered if the scour score was $>3$. Calf fecal consistency was monitored daily using both procedures to determine scour occurrences, with results for DS from the new procedure compared with the Larson et al. (1977) procedure for validation purposes.

Weekly measurements of BW, withers height (WH), hip height (HH), hip width (HW), and heart girth (HG) were recorded. Blood samples $(25 \mathrm{~mL})$ were collected weekly at $4 \mathrm{~h}$ post-a.m. milk feeding via jugular venipuncture into evacuated tubes containing EDTA for blood hematocrit (HEM), plasma total protein (PTP), plasma BHBA, and blood VFA determination. Blood samples from wk 4 and 5 were analyzed for acetate, propionate, butyrate, and total blood VFA concentration, as described by Quigley et al. (1991), using ion exchange cleanup and gas chromatography. Plasma BHBA was determined on wk 3 through 6 samples using the Stanbio $\beta$-hydroxybutyrate LiquiColor kit (procedure no. 2440, Stanbio Laboratory, Boerne, TX). Blood HEM and PTP were determined according to Naylor and Kronfeld (1977) and McBeath et al. (1971), respectively, for wk 0 to 6 .

\section{Rumen Tissue Sampling}

A subset of 12 male calves (3/treatment) was euthanized at 4 wk of age using captive bolt stunning and exsanguination. Digestive tracts were harvested, emptied, and rinsed with cold water, and rumen tissue samples were collected for analysis of papillae length (PL), papillae width (PW), and rumen wall thickness (RWT) according to Lesmeister et al. (2004).

\section{Rumen Cannulation Experiment}

Twelve male Holstein calves were ruminally fistulated with $28 \mathrm{~mm}$ (i.d.) rubber cannulas (Macam Rubber Pty. Ltd., Baulkham Hills, Australia) at $7 \pm 1 \mathrm{~d}$ of age, randomly assigned to the 4 treatments, and blocked by birth date (3/treatment). Experimental procedures were approved by the Penn State Animal Care and Use Committee.

In an attempt to equalize early starter intake, starter was manually inserted into the rumen in an amount equal to the calf within the block having the highest intake until voluntary intake occurred. At least one calf per treatment required manual starter insertion during wk 2 of the experiment, after which voluntary intake was sufficient enough to make starter insertion unnecessary.

Rumen fluid ( $15 \mathrm{~mL}$ ) was obtained via the cannula using a small metal tube fitted with a $1-\mu \mathrm{m}$ filtering screen attached to a $20-\mathrm{mL}$ syringe. Blood samples (20 $\mathrm{mL}$ ) were collected via jugular catheter into evacuated tubes containing EDTA for plasma BHBA determination. Rumen fluid and blood samples were obtained 1 $\mathrm{d} /$ wk during wk $2,3,4,5$, and 6 . Sampling was performed at 0 and $6 \mathrm{~h}$ post-a.m. milk feeding during wk 2 and every $2 \mathrm{~h}$ over a 22 -h period during wk $3,4,5$, and 6. Rumen fluid $\mathrm{pH}$ was immediately determined ( $\mathrm{pH}$ meter, model M90, Corning, Inc., Corning, NY). Ruminal fluid (15 mL) was then placed into bottles containing $3 \mathrm{~mL}$ of $25 \%$ metaphosphoric acid and $3 \mathrm{~mL}$ of $0.6 \%$ 2-ethyl butyric acid (internal standard) and stored at $-20^{\circ} \mathrm{C}$ until VFA and $\mathrm{NH}_{3}$ analyses were conducted. Samples were later centrifuged 3 times at 4,000 $\times g$ for 30 min at $4^{\circ} \mathrm{C}$ to obtain clear supernatant. Supernatant was analyzed for rumen $\mathrm{NH}_{3}$ using a phenolhypochlorite assay (Broderick and Kang, 1980) and molar concentration of VFA by gas chromatography (Yang and Varga, 1989). Plasma BHBA for calves used in the cannulation experiment was determined for wk 5 and 6 according to the same methods used in the growth experiment.

\section{Statistical Analyses}

Data for intake, growth, and blood parameters were analyzed as a randomized complete block design with 
23 blocks, whereas the rumen development data were analyzed as a completely randomized design. A repeated measures analysis was conducted using the MIXED procedure of SAS (1999), with block and calf used as the random effect for the growth and rumen development analyses, respectively. Differences were noted at $P<0.05$ and $P<0.10$ for the growth and rumen development analyses, respectively. The statistical model used for analyses was:

$$
y_{p t c}=\mu+\alpha_{p}+\beta_{t}+(\alpha \beta)_{p t}+e_{p t c}
$$

where $y_{p t c}=$ an observed value for BW, DMI, FE, $\mathrm{HH}$, WH, HW, HG, HEM, PTP, BHBA, blood VFA, PL, PW, or RWT taken from calf $c$ receiving corn processing method $p$ at time $t ; \mu=$ the overall mean of the population; $\alpha_{p}=$ the fixed effect of corn processing method $p$, where $p=\mathrm{WC}, \mathrm{DRC}, \mathrm{RC}$, or SFC; $\beta_{t}=$ the random effect of the measurement taken at time $t$, where $t=1$ to 42 $\mathrm{d}$ for intake analysis from the growth experiment; 0 to 6 wk for growth, HEM, and PTP analyses; 3 to $6 \mathrm{wk}$ for plasma BHBA analysis, and 4 or 5 wk for blood VFA analyses; $(\alpha \beta)_{p t}=$ the effect of the interaction between corn processing method $p$ and the measurement taken at time $t ; e_{p t c}=$ the error associated with the measurement taken from calf $c$ receiving corn processing method $p$ at time $t ; e_{p t c} \stackrel{i d}{\approx} N\left(0, \sigma_{\mathrm{e}}^{2}\right)$.

Birth weight was included in the model as a covariate for preweaning and overall $\mathrm{ADG}$ analyses, and weaning weight was the covariate for postweaning ADG analysis. Initial measurements for $\mathrm{HH}, \mathrm{WH}, \mathrm{HG}$, and $\mathrm{HW}$ were included in the model as covariates for their respective analyses. For the HEM analysis, PTP was included as a covariate. The model for analysis of rumen development parameters did not include a time $(\beta)$ or treatment $\times$ time interaction $(\alpha \beta)$ effect. Starter DMI was used as a covariate for all rumen development analyses. A sex effect was included in all models, except for rumen development, but was not significant.

Data from the cannulation experiment were analyzed as a randomized block design with 3 blocks. Double repeated measures (week and hour) analysis was conducted using the MIXED procedure of SAS (1999), with block used as the random effect. Differences were observed at $P<0.05$. The statistical model used was:

$$
y_{p h w c}=\mu+\alpha_{p}+\beta_{h}+\chi_{w}+(\alpha \beta)_{p h}+(\alpha \chi)_{p w}+e_{p h w c},
$$

where $y_{p h w c}=$ an observed value for rumen $\mathrm{pH}, \mathrm{NH}_{3}$, VFA, or plasma BHBA from the calf $c$ receiving corn processing method $p$ taken during the week $w$ at hour $h ; \mu=$ the overall mean of the population; $\alpha_{p}=$ the fixed effect of corn processing method $p$, where $p=\mathrm{WC}, \mathrm{DRC}$,
Table 1. Ingredient composition of texturized calf starter containing

\begin{tabular}{|c|c|}
\hline Ingredients & $\% \mathrm{DM}$ \\
\hline Corn grain & 33.29 \\
\hline Cane molasses & 5.08 \\
\hline Oats & 15.54 \\
\hline \multicolumn{2}{|l|}{ Premix pellet } \\
\hline Wheat midds & 17.09 \\
\hline Soybean meal & 23.92 \\
\hline Calcium carbonate & 2.35 \\
\hline Dicalcium phosphate & 1.26 \\
\hline Salt & 0.94 \\
\hline Vitamin A premix $^{1}$ & 0.02 \\
\hline Vitamin $\mathrm{B}-12^{2}$ & 0.001 \\
\hline $\operatorname{Deccox}^{3}$ & 0.06 \\
\hline Vitamin $\mathrm{E}^{4}$ & 0.009 \\
\hline Vitamin $\mathrm{D}^{5}$ & 0.008 \\
\hline Magnesium oxide & 0.09 \\
\hline Riboflavin $^{6}$ & 0.009 \\
\hline Selenium ${ }^{7}$ & 0.11 \\
\hline Calcium propionate & 0.05 \\
\hline Trace mineral premix & 0.016 \\
\hline Flavor & 0.16 \\
\hline
\end{tabular}
whole, dry-rolled, roasted-rolled, or steam-flaked corn.

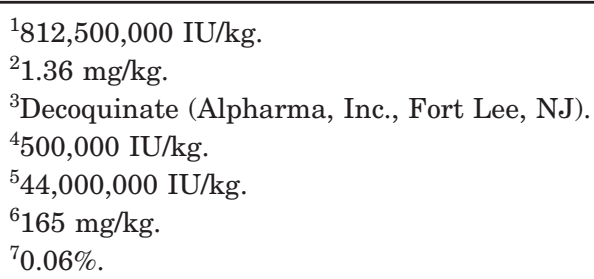

$\mathrm{RC}$, or SFC; $\beta_{h}=$ the fixed effect of hour $h$, where $h=$ 0 to $22 \mathrm{~h}$ post-a.m. milk feeding; $\chi_{w}=$ the fixed effect of week $w$, where $w=2,3,4,5$, or 6 wk for rumen parameter analyses and wk 5 or 6 for plasma BHBA analysis; $(\alpha \beta)_{p h}=$ the interaction effect between corn processing method $p$ and hour $h ;(\alpha \chi)_{p w}=$ the interaction effect between corn processing method $p$ and week $w ; e_{p h w c}=$ the error associated with the measurement taken from calf $c$ receiving corn processing method $p$ during week w at hour $h ; e_{p h w c} \stackrel{i d}{\approx} N\left(0, \sigma_{\mathrm{e}}^{2}\right)$.

Analysis of starter DMI for calves used in the cannulation experiment was conducted in the same manner as in the growth experiment. Due to the known interactions between starter DMI, rumen development, and rumen VFA production, starter DMI was used as a covariate in all cannulation experiment analyses.

\section{RESULTS AND DISCUSSION}

\section{Diet Composition}

Starter ingredient composition was identical for all texturized calf starters by design (Table 1), and nutrient compositions were similar between the starters (Table 2). Starter containing DRC had higher $\mathrm{P}$ and $\mathrm{K}$ content than SFC starter. The DRC and SFC were obtained from different sources, so the effect of processing 
Table 2. Nutrient composition and particle size distribution of texturized calf starter containing whole (WC), dry-rolled (DRC), roasted-rolled (RC), or steam-flaked (SFC) corn. ${ }^{1}$

\begin{tabular}{|c|c|c|c|c|c|}
\hline & WC & DRC & $\mathrm{RC}$ & $\mathrm{SFC}$ & SEM \\
\hline \multicolumn{6}{|l|}{ Nutrients } \\
\hline $\mathrm{DM} \%$ & 90.83 & 90.42 & 90.05 & 89.92 & - \\
\hline CP \% & 21.13 & 21.45 & 20.93 & 21.03 & 0.27 \\
\hline Soluble CP, \% CP & 16.18 & 16.30 & 17.15 & 17.25 & 1.21 \\
\hline TDN, $\%^{2}$ & 75.22 & 75.71 & 75.60 & 75.82 & 0.14 \\
\hline $\mathrm{NE}_{\mathrm{M}}, \mathrm{Mcal} / \mathrm{kg}^{2}$ & 2.24 & 2.26 & 2.25 & 2.26 & 0.01 \\
\hline $\mathrm{NE}_{\mathrm{G}}, \mathrm{Mcal} / \mathrm{kg}^{2}$ & 1.70 & 1.72 & 1.71 & 1.72 & 0.01 \\
\hline $\mathrm{ADF}, \%$ & 7.70 & 7.80 & 7.98 & 7.56 & 0.29 \\
\hline NDF, \% & 17.78 & 17.85 & 18.48 & 17.63 & 0.43 \\
\hline Ash, \% & 10.65 & 10.13 & 10.05 & 10.08 & 0.35 \\
\hline Starch, \% & 30.95 & 30.65 & 31.00 & 31.83 & 0.77 \\
\hline Sugar, \% & 6.18 & 6.55 & 6.65 & 5.93 & 0.30 \\
\hline $\mathrm{NSC}, \%$ & 37.18 & 37.20 & 37.65 & 37.75 & 0.57 \\
\hline $\mathrm{Ca}, \%$ & 1.61 & 1.55 & 1.69 & 1.63 & 0.08 \\
\hline $\mathrm{P}, \%$ & $0.91^{\mathrm{ab}}$ & $0.96^{\mathrm{a}}$ & $0.92^{\mathrm{ab}}$ & $0.87^{\mathrm{b}}$ & 0.02 \\
\hline $\mathrm{Mg}, \%$ & 0.32 & 0.36 & 0.34 & 0.34 & 0.01 \\
\hline $\mathrm{K}, \%$ & $1.19^{\mathrm{ab}}$ & $1.23^{\mathrm{a}}$ & $1.21^{\mathrm{ab}}$ & $1.14^{\mathrm{b}}$ & 0.04 \\
\hline $\mathrm{Na}, \%$ & 0.379 & 0.375 & 0.407 & 0.386 & 0.015 \\
\hline $\mathrm{Fe}, \mathrm{ppm}$ & 285 & 309 & 313 & 296 & 12 \\
\hline $\mathrm{Mn}, \mathrm{ppm}$ & 85 & 90 & 93 & 94 & 10 \\
\hline $\mathrm{Zn}, \mathrm{ppm}$ & 110 & 116 & 112 & 113 & 9 \\
\hline $\mathrm{Cu}, \mathrm{ppm}$ & 17 & 18 & 18 & 20 & 2 \\
\hline \multicolumn{6}{|c|}{ Particle size, $\%$ retained } \\
\hline $6.70 \mathrm{~mm}$ & 20.70 & 0.86 & 21.88 & 10.48 & - \\
\hline $4.75 \mathrm{~mm}$ & 14.68 & 14.16 & 13.17 & 12.33 & - \\
\hline $3.35 \mathrm{~mm}$ & 42.51 & 63.46 & 39.72 & 39.73 & - \\
\hline $2.36 \mathrm{~mm}$ & 17.27 & 17.05 & 18.19 & 20.78 & - \\
\hline $1.70 \mathrm{~mm}$ & 2.94 & 3.19 & 4.38 & 6.66 & - \\
\hline $1.18 \mathrm{~mm}$ & 0.75 & 0.52 & 1.01 & 2.73 & - \\
\hline $0.60 \mathrm{~mm}$ & 0.60 & 0.41 & 0.93 & 3.73 & - \\
\hline pan & 0.56 & 0.23 & 0.71 & 3.60 & - \\
\hline
\end{tabular}

${ }^{\mathrm{a}, \mathrm{b}}$ Means within a row without common superscripts are different at $P<0.05$.

${ }^{1}$ All values reported on DM basis.

${ }^{2} \mathrm{TDN}=$ Total digestible nutrients, $\mathrm{NE}_{\mathrm{M}}=$ net energy of maintenance, $\mathrm{NE}_{\mathrm{G}}=$ net energy of gain; Calculated using National Research Council (2001).

method on mineral composition may be confounded with differences in corn variety and environmental conditions.

Particle size analysis revealed that particles retained on the top 2 screens were predominately WC and whole pellets for the 6.70 - and $4.75-\mathrm{mm}$ screens, respectively. Retained particles on the $3.35-\mathrm{mm}$ screen were fragmented corn kernels and pellets, with oats being retained on the 2.36-mm screen. Particles retained by the remaining screens consisted of severely fragmented corn and pellet particles, minerals, and ration fines. Dry-rolling corn reduced corn particles retained by the $6.70-\mathrm{mm}$ screen but increased corn particles on the $3.35-\mathrm{mm}$ screen, a result expected due to the processing method used during dry-rolling. Steam-flaking corn also decreased corn particles retained by the $6.70-\mathrm{mm}$ screen. Smaller particles in calf starters can negatively influence rumen epithelial health due to their limited ability to physically remove dying epithelial cells and their tendency to become trapped between papillae, resulting in rumen parakeratosis (Beharka et al., 1998).

\section{Growth Experiment}

Intake and weight gain. Table 3 presents least square means for initial, weaning, and final BW, ADG, FE (feed:gain), and milk replacer, starter, and total DM intake. Values for ADG, DMI, and FE are presented for preweaned (wk 1 to 4), postweaned (wk 5 and 6), and overall (wk 1 to 6 ) periods. Initial BW, and therefore, milk replacer DMI were not different between treatments. During the preweaning period, no treatment differences were detected for DMI, ADG, or FE, and weaning BW was similar for all treatments. Postweaning, DRC calves consumed more starter than RC and SFC calves. In addition, calves receiving WC starter had greater starter DMI than SFC calves and tended to have greater starter DMI than RC calves $(P=$ 0.10). Calves receiving SFC starter exhibited the lowest $\mathrm{ADG}$ during the postweaning period, gaining less $\mathrm{BW}$ than DRC calves and tending to gain less than WC calves $(P=0.06)$. In addition, $\mathrm{FE}$ was lower for SFC calves than DRC and WC calves during the postwean- 
Table 3. Least square means for intake and BW of Holstein calves receiving whole (WC), dry-rolled (DRC), roasted-rolled (RC), or steam-flaked (SFC) corn in a texturized calf starter.

\begin{tabular}{|c|c|c|c|c|c|c|}
\hline & \multirow[b]{2}{*}{$\mathrm{n}$} & \multicolumn{4}{|c|}{ Treatment } & \multirow[b]{2}{*}{ SEM } \\
\hline & & WC & $\mathrm{DRC}$ & $\mathrm{RC}$ & SFC & \\
\hline \multicolumn{7}{|l|}{ BW, kg } \\
\hline Initial & 92 & 41.69 & 41.79 & 43.08 & 42.40 & 0.95 \\
\hline Weaning & 92 & 51.76 & 51.70 & 53.31 & 52.27 & 1.28 \\
\hline Final & 80 & 62.36 & 61.29 & 62.83 & 60.31 & 1.58 \\
\hline \multicolumn{7}{|l|}{ Daily gain, $\mathrm{g} / \mathrm{d}$} \\
\hline Wk 1 to 4 & 92 & 354 & 358 & 354 & 345 & 26 \\
\hline Wk 5 and 6 & 80 & $721^{\mathrm{ab}}$ & $743^{\mathrm{a}}$ & $644^{\mathrm{ab}}$ & $555^{\mathrm{b}}$ & 62 \\
\hline Wk 1 to 6 & 92 & 469 & 474 & 455 & 433 & 25 \\
\hline \multicolumn{7}{|c|}{ Predicted daily gain, ${ }^{1} \mathrm{~g} / \mathrm{d}$} \\
\hline Wk 1 to 4 & - & 370 & 380 & 370 & 360 & - \\
\hline Wk 5 and 6 & - & 380 & 460 & 310 & 310 & - \\
\hline Wk 1 to 6 & - & 380 & 420 & 350 & 350 & - \\
\hline \multicolumn{7}{|l|}{ DMI, g/d } \\
\hline \multicolumn{7}{|l|}{ Milk replacer } \\
\hline Wk 1 to 4 & 92 & 519 & 521 & 536 & 528 & 12 \\
\hline \multicolumn{7}{|l|}{ Starter } \\
\hline Wk 1 to 4 & 92 & 164 & 172 & 131 & 126 & 18 \\
\hline Wk 5 and 6 & 80 & $1253^{\mathrm{ab}}$ & $1354^{\mathrm{a}}$ & $1148^{\mathrm{bc}}$ & $1119^{c}$ & 50 \\
\hline Wk 1 to 6 & 92 & $551^{\mathrm{ab}}$ & $589^{\mathrm{a}}$ & $503^{\mathrm{bc}}$ & $479^{c}$ & 24 \\
\hline \multicolumn{7}{|l|}{ Total } \\
\hline Wk 1 to 4 & 92 & 683 & 693 & 665 & 654 & 21 \\
\hline Wk 1 to 6 & 92 & $885^{\mathrm{ab}}$ & $923^{\mathrm{a}}$ & $847^{\mathrm{bc}}$ & $819^{c}$ & 25 \\
\hline \multicolumn{7}{|l|}{$\mathrm{FE}^{2}$} \\
\hline Wk 1 to 4 & 92 & 2.05 & 2.33 & 2.20 & 2.08 & 0.22 \\
\hline Wk 5 and 6 & 80 & $1.89^{\mathrm{a}}$ & $1.88^{\mathrm{a}}$ & $2.07^{\mathrm{ab}}$ & $2.33^{\mathrm{b}}$ & 0.14 \\
\hline Wk 1 to 6 & 92 & 1.88 & 2.03 & 2.03 & 2.14 & 0.11 \\
\hline
\end{tabular}

a,b,c Means within a row without common superscripts are different at $P<0.05$.

${ }^{1}$ Predicted using National Research Council (2001).

${ }^{2}$ Feed efficiency, expressed as a ratio of kilogram of feed to kilogram of gain.

ing period. However, observed treatment differences for postweaning ADG and starter DMI did not result in final BW differences between treatments. In addition, during the postweaning period, $\mathrm{ADG}$ was not different between $\mathrm{DRC}$ and RC calves, despite the greater starter DMI of DRC calves. Coupling this observation with the similar postweaning $\mathrm{FE}$ observed between DRC and $\mathrm{RC}$ calves may indicate an increased ability for calves receiving starter containing $\mathrm{RC}$ to convert ingested nutrients into BW gain. Overall, starter DMI was lowest for calves receiving SFC starter. However, overall ADG and $\mathrm{FE}$ were not different between treatments, although calves receiving SFC starter tended to require more feed per kilogram of gain than WC calves $(P=$ 0.08 ).

Starter DMI in the current study was highest in calves receiving DRC starter, followed by WC, then RC calves, with SFC calves consuming the least starter, supporting previously reported intake trends found in mature ruminants (Owens et al., 1997). Intake differences observed in the current study were carried over into postweaning $\mathrm{ADG}$ differences between calves receiving DRC and SFC starters. Heat processing has been shown to increase postruminal energy availability (Huntington, 1997; Crocker et al., 1998), and prerumi- nant calves are forced to rely more on postruminal nutrients due to ruminal immaturity. Therefore, calves receiving RC or SFC starter may have been more likely to meet their nutrient requirements for growth than calves receiving WC or DRC starter, possibly explaining the differences in feed efficiency observed in the current study. Previous research conducted with mature ruminants has indicated similar BW gains when rations contained either DRC or SFC (Theurer, 1986; Owens et al., 1997). Results from the current study either do not support these findings or indicate a difference between mature and immature ruminants in their ability to use processed corn. In addition, trends for FE are in contrast to those previously reported (Theurer, 1986; Owens et al., 1997). In the current study, calves receiving WC starter were most efficient, followed by DRC, and RC calves, with SFC calves being least efficient.

Observed ADG from the current study was compared with predicted ADG (NRC, 2001). The NRC (2001) identified a void in the literature for calorimetric and/or comparative slaughter research conducted with weaned, ruminant calves weighing less than $100 \mathrm{~kg}$. In addition, Blaxter (1967) indicated decreases in energy and protein use efficiencies for growth as calves aged, 
Table 4. Least square means for structural growth measurements of Holstein calves receiving whole (WC), dry-rolled (DRC), roasted-rolled (RC), or steam-flaked (SFC) corn in a texturized calf starter.

\begin{tabular}{|c|c|c|c|c|c|c|}
\hline & \multirow[b]{2}{*}{$\mathrm{n}$} & \multicolumn{4}{|c|}{ Treatment } & \multirow[b]{2}{*}{ SEM } \\
\hline & & WC & DRC & $\mathrm{RC}$ & SFC & \\
\hline \multicolumn{7}{|l|}{ Hip height } \\
\hline Initial, $\mathrm{cm}$ & 80 & 79.47 & 79.12 & 80.43 & 79.70 & 0.50 \\
\hline Final, cm & 80 & 85.76 & 85.66 & 86.77 & 85.66 & 0.53 \\
\hline Change, $\mathrm{cm} / \mathrm{d}$ & 80 & 0.15 & 0.15 & 0.16 & 0.14 & 0.01 \\
\hline \multicolumn{7}{|l|}{ Wither height } \\
\hline Initial, $\mathrm{cm}$ & 80 & $75.79^{b}$ & $75.79^{b}$ & $77.22^{\mathrm{a}}$ & $76.49^{\mathrm{ab}}$ & 0.47 \\
\hline Final, cm & 80 & $82.42^{\mathrm{ab}}$ & $82.36^{\mathrm{ab}}$ & $83.50^{\mathrm{a}}$ & $82.14^{b}$ & 0.44 \\
\hline Change, $\mathrm{cm} / \mathrm{d}$ & 80 & 0.15 & 0.16 & 0.16 & 0.14 & 0.01 \\
\hline \multicolumn{7}{|l|}{ Hip width } \\
\hline Initial, $\mathrm{cm}$ & 80 & $17.89^{\mathrm{ab}}$ & $17.61^{\mathrm{b}}$ & $18.24^{\mathrm{a}}$ & $18.21^{\mathrm{a}}$ & 0.15 \\
\hline Final, cm & 80 & $20.34^{\mathrm{ab}}$ & $20.15^{\mathrm{b}}$ & $20.65^{\mathrm{a}}$ & $20.27^{\mathrm{ab}}$ & 0.19 \\
\hline Change, $\mathrm{cm} / \mathrm{d}$ & 80 & $0.06^{\mathrm{a}}$ & $0.06^{\mathrm{a}}$ & $0.06^{\mathrm{a}}$ & $0.05^{\mathrm{b}}$ & $<0.01$ \\
\hline \multicolumn{7}{|l|}{ Heart girth } \\
\hline Initial, $\mathrm{cm}$ & 80 & 76.94 & 76.78 & 78.20 & 77.70 & 0.59 \\
\hline Final, cm & 80 & $86.96^{\mathrm{ab}}$ & $86.14^{\mathrm{b}}$ & $88.29^{\mathrm{a}}$ & $86.07^{\mathrm{b}}$ & 0.70 \\
\hline Change, $\mathrm{cm} / \mathrm{d}$ & 80 & $0.23^{\mathrm{ab}}$ & $0.21^{\mathrm{b}}$ & $0.25^{\mathrm{a}}$ & $0.21^{\mathrm{b}}$ & 0.01 \\
\hline
\end{tabular}

${ }^{\mathrm{a}, \mathrm{b}}$ Means within a row without common superscripts are different at $P<0.05$.

body weight and fat deposition increased, and diet changed.

Observed preweaning ADG was slightly lower for all treatments than ADG predicted by the NRC (2001) model. During the postweaning period, observed ADG was greater for all treatments than predicted by the NRC (2001) model, indicating more efficient starter nutrient use than assumed by the model. Comparisons between actual and predicted ADG for the postweaning and overall periods must be interpreted carefully and may not be valid due to weaning age, BW, gut fill, and dietary differences between the current study data and NRC (2001) data.

Structural growth. Least square means for initial, final, and average daily change of $\mathrm{HH}, \mathrm{WH}, \mathrm{HW}$, and HG are presented in Table 4. There were no significant treatment differences observed for initial, daily change, and final $\mathrm{HH}$. Initial WH was greater in calves receiving $\mathrm{RC}$ starter than WC or DRC starter. Daily WH change was not different between these 3 treatments, but a greater initial $\mathrm{WH}$ carried over into a tendency for greater final $\mathrm{WH}$ in $\mathrm{RC}$ calves than $\mathrm{WC}(P=0.09)$ or DRC $(P=0.07)$ calves. Calves receiving DRC starter exhibited the lowest initial HW and were narrower across the hips than RC or SFC calves. However, a greater daily $\mathrm{HW}$ change for DRC than SFC calves resulted in no difference for final HW between these 2 treatments. In contrast, daily HW change was similar between calves receiving DRC starter and RC starter; therefore, final HW was greater for RC than DRC calves. Higher daily $\mathrm{HW}$ change for $\mathrm{WC}$ and $\mathrm{RC}$ calves when compared with SFC calves was not sufficient to result in differences for final HW between these treatments. Initial HG measurements were not significantly different between treatments. However, daily HG change was significantly greater in calves receiving $\mathrm{RC}$ starter than DRC or SFC starter. Due to increased HG growth, calves receiving $\mathrm{RC}$ had a significantly greater final HG than calves receiving DRC or SFC starter. No other treatment differences were observed for HG measurements, and these observed differences were biologically quite small.

Results for structural growth observed in the current study indicate that processing method may influence partitioning of intake nutrients to bone or fat deposition, likely due to differences in postruminal nutrient availability between processing methods (Theurer, 1986; Owens et al., 1997). This was especially evident for calves fed RC starter, as they consumed less starter $\mathrm{DM}$ and had similar ADG and greater structural growth when compared with calves fed DRC starter. The same was partially true for calves fed RC or SFC starter when compared with calves fed WC starter. Therefore, it is possible that intake nutrients are partitioned to skeletal or fat deposition when calves consume starters containing heat processed or physically processed corn, respectively. Previous work with processed sorghum, however, showed no differences in growth of calves (Schuh et al., 1970; Abdelgadir and Morrill, 1995), with a tendency for calves fed flaked sorghum to eat more of the grain.

Blood parameters. There were no treatment effects for blood parameters measured over time; therefore, Table 5 presents overall least square means for HEM, PTP, plasma BHBA, and blood VFA concentrations. Blood concentrations of acetate, propionate, butyrate, and total VFA were higher in calves receiving starter containing SFC than in calves receiving starters con- 
Table 5. Least square means for blood parameter measurements, days scoured, respiratory score, and general appearance score of Holstein calves receiving whole (WC), dry-rolled (DRC), roasted-rolled (RC), or steam-flaked (SFC) corn in a texturized calf starter.

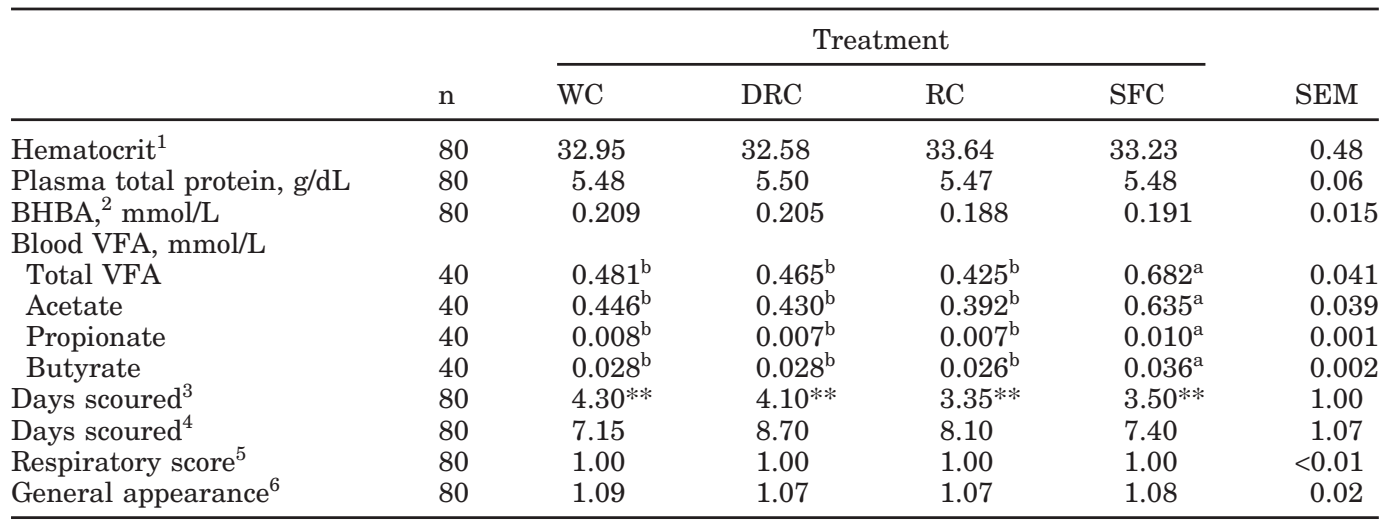

**Indicates difference between scour scoring procedures at $P<0.05$.

${ }^{\mathrm{a}, \mathrm{b}}$ Means within a row without common superscripts are different at $P<0.05$.

${ }^{1}$ Blood hematocrit volume - percent of whole blood.

${ }^{2}$ Plasma $\beta$-hydroxybutyrate.

${ }^{3}$ Larson et al. (1977).

${ }^{4}$ Scour scoring: 1 = normal, 2 = soft to loose, $3=$ loose to watery, 4 = watery, mucous, slightly bloody, $5=$ watery, mucous, and bloody. Scour day considered if score $>3$.

${ }^{5}$ Respiratory scoring: 1 = normal, 2 = slight cough, 3 = moderate cough, $4=$ moderate to severe cough, $5=$ severe and chronic cough.

${ }^{6}$ General appearance scoring: $1=$ normal and alert, $2=$ ears drooped, $3=$ head and ears drooped, dull eyes, slightly lethargic, $4=$ head and ears drooped, dull eyes, lethargic, $5=$ severely lethargic.

taining WC, DRC, or RC. Increased blood VFA concentrations in calves receiving SFC starter may indicate increased rumen epithelial metabolic activity and/or increased rumen VFA concentrations. However, the relationships between peripheral blood VFA, rumen epithelial metabolic activity, and rumen VFA concentrations have not been completely elucidated.

Calf health. Least square means for DS, respiratory score, and general appearance score are presented in Table 5. Calves were generally healthy; no significant treatment differences for DS, respiratory score, and general appearance score were observed utilizing the new procedure. However, the new procedure indicated more DS than the Larson et al. (1977) procedure, suggesting that the new procedure may be more sensitive. Results for treatment comparisons were similar between the 2 procedures, indicating that both procedures are effective in determining treatment effects.

Rumen development. Least square means for PL, PW, and RWT from the subset of calves used to determine the influence of grain processing on rumen development parameters are presented in Table 6. Papillae were longer in calves receiving SFC starter than in calves receiving DRC starter, despite lower starter intake for SFC calves. Rumen absorptive surface area increases as PL and PW increase. Therefore, the increased PL for SFC calves may explain the higher blood VFA concentrations observed in calves receiving SFC.
The RWT in calves receiving SFC starter was greater than in WC calves $(P<0.07)$. However, the SFC ration had more fine particles that may have become trapped by rumen papillae or were less effective in removing dying epithelial cells, subsequently resulting in keratin buildup and rumen mucosa thickening (Beharka et al., 1998). No differences were observed between treatments for PW.

\section{Rumen Cannulation Experiment}

Starter intake. Least square means for average daily starter DMI treatment $\times$ week effects from wk 2 through 6 are presented in Table 7. No differences in starter DMI were detected in the cannulated calves, but calves receiving DRC starter consumed numerically more starter DMI during wk 3 to 6 as observed in the growth experiment. However, due to the low number of calves per treatment (3), differences in starter DMI failed to reach significance.

Rumen $\boldsymbol{p H}$. Least square means of rumen $\mathrm{pH}$ for treatment $\times$ week are presented in Table 8 . Although rumen $\mathrm{pH}$ was greatest in WC calves throughout the study, differences between processing methods were inconsistent. Significant treatment $\times$ week interactions were observed during wk 4, 5, and 6 .

Higher rumen $\mathrm{pH}$ in WC calves may indicate a moderate buffering effect of unprocessed grains, when concen- 
Table 6. Least square means for rumen development measurements of Holstein calves ( 4 wk of age) receiving whole (WC), dry-rolled (DRC), roasted-rolled (RC), or steam-flaked (SFC) corn in a texturized calf starter.

\begin{tabular}{lllllll}
\hline & & \multicolumn{4}{c}{ Treatment } & SEM \\
\cline { 3 - 6 } & $\mathrm{n}$ & $\mathrm{WC}$ & DRC & RC & SFC & SEM \\
\hline Papillae length, cm & 12 & $0.87^{\mathrm{ab}}$ & $0.71^{\mathrm{b}}$ & $0.80^{\mathrm{ab}}$ & $0.89^{\mathrm{a}}$ & 0.07 \\
Papillae width, cm & 12 & 0.57 & 0.54 & 0.51 & 0.61 & 0.07 \\
Rumen wall thickness, cm & 12 & $1.06^{\mathrm{b}}$ & $1.10^{\mathrm{ab}}$ & $1.14^{\mathrm{ab}}$ & $1.21^{\mathrm{a}}$ & 0.05 \\
\hline
\end{tabular}

${ }^{\mathrm{a}, \mathrm{b}}$ Means within a row without common superscripts are different at $P<0.10$.

trates are fed at a high percentage of the diet. Similar processing effects on rumen $\mathrm{pH}$ were reported by Murphy et al. (1994), who found decreased ruminal $\mathrm{pH}$ in feedlot steers fed diets containing DRC when compared with steers consuming diets with WC. Calves in the current study did not receive forages in their diets; therefore, solid feedstuffs entering the rumen consisted primarily of rapidly degradable concentrates. However, rumen $\mathrm{pH}$ levels observed in the current study were not dramatically low for young dairy calves, and similar rumen $\mathrm{pH}$ levels for calves of comparable age have been previously reported (Vazquez-Anon et al., 1993). Rumen $\mathrm{pH}$ decreased linearly $(P<0.01)$ as calves aged in the current study.

Rumen $\mathrm{NH}_{3}$ concentration. Least square means for rumen $\mathrm{NH}_{3}$ concentrations by week are presented in Table 8. Although significant treatment $\times$ week interactions for rumen $\mathrm{NH}_{3}$ concentration were observed during wk 2, 4, and 6, changes were inconsistent and highly variable. Rumen $\mathrm{NH}_{3}$ concentration changed quadratically $(P<0.01)$ as calves aged in the current study.

Crocker et al. (1998) reported decreasing rumen $\mathrm{NH}_{3}$ concentration as SFC replaced DRC, attributing this effect to increased microbial use of available $\mathrm{NH}_{3}$. In addition, others have reported a tendency for decreasing rumen $\mathrm{NH}_{3}$ concentrations as starch degradability increased (Aldrich et al., 1993). Rumen $\mathrm{NH}_{3}$ concentrations observed in the current study fluctuated drastically across all treatments and do not indicate any definite effect of heat processing or mechanical pro-

Table 7. Least square means for average daily starter DMI (g/d) treatment by week effect from ruminally cannulated Holstein calves receiving whole (WC), dry-rolled (DRC), roasted-rolled (RC), or steamflaked (SFC) corn in a texturized calf starter.

\begin{tabular}{lrrrrr}
\hline & \multicolumn{4}{c}{ Treatment } & \\
\cline { 2 - 5 } Week & WC & DRC & \multicolumn{1}{c}{ RC } & SFC & SEM \\
\hline 2 & 11 & 8 & 6 & 15 & 7 \\
3 & 49 & 56 & 21 & 48 & 28 \\
4 & 89 & 112 & 63 & 111 & 70 \\
5 & 388 & 675 & 424 & 361 & 237 \\
6 & 687 & 1286 & 1033 & 904 & 219 \\
\hline
\end{tabular}

cessing on rumen $\mathrm{NH}_{3}$ concentrations. Rumen $\mathrm{NH}_{3}$ concentrations did appear to decrease as starter intake increased, indicating ruminal microbial proliferation and increased incorporation of $\mathrm{NH}_{3}$ nitrogen into microbial protein.

Rumen VFA concentrations. Least square means of total and individual VFA concentrations for treatment $\times$ week are presented in Table 9. Total rumen VFA, acetate, and propionate concentrations were generally lowest in calves receiving WC starter and highest in calves receiving SFC starter. Total VFA, acetate, and propionate concentrations increased linearly $(P<0.01)$ as calves aged in the current study.

Total rumen VFA concentration results support findings in feedlot steers and in vitro studies (Trei et al., 1970; Murphy et al., 1994). Conversely, others have reported no differences in total rumen VFA production when steam-flaked, steam-rolled, dry-rolled, and coarse-ground grains were fed to lactating cows (Crocker et al., 1998). However, no forages were offered to calves in the current study, possibly explaining differing results between the current study and those utilizing lactating cows.

Ruminal acetate and propionate concentrations appeared to increase as the extent of processing increased, with calves receiving SFC starter having the highest concentrations. Similar results for propionate have been reported in lactating dairy cows, with SFC increasing ruminal propionate at the expense of acetate and butyrate (Crocker et al., 1998). Conversely, ruminal propionate production decreased when DRC replaced WC in feedlot steer rations (Murphy et al., 1994). Acetate production results from the current study contradict previously reported results in lactating cows and feedlot steers (Joy et al., 1997). Conflicting results may be explained by dietary forage incorporation in previous studies and reported differences in rumen dynamics between mature and immature ruminants (VazquezAnon et al., 1993).

Rumen butyrate concentration was higher in calves receiving $\mathrm{RC}$ starter than in calves receiving $\mathrm{DRC}$ or SFC starter during wk 5. No other treatment effects were observed. However, rumen butyrate concentration 
Table 8. Least square means for rumen $\mathrm{pH}$ and $\mathrm{NH}_{3}$ treatment by week effect from ruminally cannulated Holstein calves receiving whole (WC), dry-rolled (DRC), roasted-rolled (RC), or steam-flaked (SFC) corn in a texturized calf starter.

\begin{tabular}{|c|c|c|c|c|c|c|}
\hline & \multirow[b]{2}{*}{ Week } & \multicolumn{4}{|c|}{ Treatment } & \multirow[b]{2}{*}{ SEM } \\
\hline & & WC & DRC & $\mathrm{RC}$ & $\mathrm{SFC}$ & \\
\hline \multirow[t]{5}{*}{$\mathrm{pH}$} & 2 & 6.81 & 6.49 & 6.56 & 6.77 & 0.18 \\
\hline & 3 & 6.58 & 6.16 & 6.50 & 6.13 & 0.19 \\
\hline & 4 & $6.31^{\mathrm{a}}$ & $6.18^{\mathrm{ab}}$ & $6.13^{\mathrm{ab}}$ & $5.66^{\mathrm{b}}$ & 0.22 \\
\hline & 5 & $5.81^{\mathrm{a}}$ & $5.45^{\text {bc }}$ & $5.37^{\mathrm{c}}$ & $5.78^{\mathrm{ab}}$ & 0.16 \\
\hline & 6 & $5.66^{\mathrm{a}}$ & $5.41^{\mathrm{b}}$ & $5.43^{\mathrm{b}}$ & $5.44^{\mathrm{b}}$ & 0.12 \\
\hline \multirow{5}{*}{$\mathrm{NH}_{3}, \mathrm{mmol} / \mathrm{L}$} & 2 & $4.204^{\mathrm{b}}$ & $10.084^{\mathrm{a}}$ & $11.414^{\mathrm{a}}$ & $7.797^{\mathrm{ab}}$ & 1.930 \\
\hline & 3 & 4.314 & 5.805 & 7.398 & 7.068 & 1.845 \\
\hline & 4 & $4.967^{\mathrm{b}}$ & $8.933^{\mathrm{ab}}$ & $8.454^{\mathrm{ab}}$ & $12.659^{\mathrm{a}}$ & 2.230 \\
\hline & 5 & 9.100 & 3.626 & 8.572 & 5.007 & 2.189 \\
\hline & 6 & $3.742^{\mathrm{ab}}$ & $3.985^{\mathrm{ab}}$ & $4.692^{\mathrm{a}}$ & $1.302^{\mathrm{b}}$ & 1.473 \\
\hline
\end{tabular}

${ }^{\mathrm{a}, \mathrm{b}, \mathrm{c}}$ Means within a row without common superscripts are different at $P<0.05$.

tended $(P=0.06)$ to be greater in calves receiving $\mathrm{DRC}$ starter when compared with calves receiving WC starter during wk 2 and tended $(P=0.10)$ to be higher in WC than SFC calves during wk 6. Butyrate concentration tended to increase quadratically $(P=0.07)$ as the calves aged with higher concentrations observed during wk 3,4 , and 5 .

Roasting of corn appears to slightly influence ruminal butyrate concentrations in ruminally developing calves, and may indicate a possible advantage in using this processing method in starter rations. Previous research has indicated decreased butyrate production with SFC (Crocker et al., 1998). Numerically decreased rumen butyrate production in calves receiving SFC starter in the current study partially supports these previous findings but make explanation of increased rumen development in these calves difficult. It is possible that the decreased ruminal butyrate concentration observed in SFC calves is a result of increased butyrate use for epithelial growth and/or an increased uptake of ruminal butyrate evidenced by a higher blood butyrate concentration for these calves.

Plasma BHBA. During wk 6 plasma BHBA was higher in calves receiving WC $(0.261 \pm 0.038 \mathrm{mmol} / \mathrm{L})$ or DRC $(0.279 \pm 0.038 \mathrm{mmol} / \mathrm{L})$ starter than in calves receiving $\mathrm{RC}(0.141 \pm 0.038 \mathrm{mmol} / \mathrm{L})$ or $\mathrm{SFC}(0.160 \pm$ $0.038 \mathrm{mmol} / \mathrm{L})$ starter, with no other differences detected.

Table 9. Least square means for total rumen VFA, acetate, propionate, and butyrate concentrations from ruminally cannulated Holstein calves receiving whole (WC), dry-rolled (DRC), roasted-rolled (RC), or steamflaked (SFC) corn in a texturized calf starter.

\begin{tabular}{llccccr}
\hline & & \multicolumn{5}{c}{ Treatment } \\
\cline { 3 - 5 } & Week & WC & DRC & RC & SFC & SEM \\
\hline Total VFA, $\mu \mathrm{mol} / \mathrm{L}$ & 2 & $5.357^{\mathrm{b}}$ & $29.836^{\mathrm{a}}$ & $23.657^{\mathrm{ab}}$ & $22.507^{\mathrm{ab}}$ & 6.909 \\
& 3 & $40.369^{\mathrm{b}}$ & $58.037^{\mathrm{ab}}$ & $47.601^{\mathrm{ab}}$ & $70.748^{\mathrm{a}}$ & 9.606 \\
& 4 & $56.749^{\mathrm{b}}$ & $66.472^{\mathrm{ab}}$ & $72.238^{\mathrm{ab}}$ & $77.916^{\mathrm{a}}$ & 8.486 \\
& 5 & 91.896 & 90.767 & 99.755 & 83.492 & 10.252 \\
Acetate, $\mu \mathrm{mol} / \mathrm{L}$ & 6 & 98.410 & 90.540 & 109.780 & 114.240 & 13.304 \\
& 2 & $4.138^{\mathrm{b}}$ & $17.604^{\mathrm{a}}$ & $15.681^{\mathrm{a}}$ & $13.880^{\mathrm{a}}$ & 3.558 \\
& 3 & $18.943^{\mathrm{b}}$ & $28.666^{\mathrm{ab}}$ & $24.987^{\mathrm{ab}}$ & $35.241^{\mathrm{a}}$ & 4.703 \\
& 4 & $27.484^{\mathrm{b}}$ & $34.005^{\mathrm{ab}}$ & $37.253^{\mathrm{ab}}$ & $41.966^{\mathrm{a}}$ & 4.317 \\
Propionate, $\mu \mathrm{mol} / \mathrm{L}$ & 5 & 43.317 & 48.101 & 49.094 & 42.552 & 4.808 \\
& 6 & 49.158 & 50.053 & 56.520 & 55.023 & 6.047 \\
& 3 & $1.092^{\mathrm{b}}$ & $8.346^{\mathrm{a}}$ & $6.214^{\mathrm{ab}}$ & $7.123^{\mathrm{a}}$ & 2.263 \\
Butyrate, $\mu \mathrm{mol} / \mathrm{L}$ & 4 & $15.139^{\mathrm{b}}$ & $21.241^{\mathrm{ab}}$ & $17.093^{\mathrm{b}}$ & $27.741^{\mathrm{a}}$ & 4.520 \\
& 5 & 20.117 & 25.260 & 24.699 & 29.162 & 4.178 \\
& 6 & 35.146 & 34.491 & 37.391 & 33.563 & 5.565 \\
& 3 & $39.434^{\mathrm{b}}$ & $33.779^{\mathrm{b}}$ & $44.645^{\mathrm{ab}}$ & $52.694^{\mathrm{a}}$ & 6.862 \\
& 3 & 0.137 & 3.878 & 1.743 & 1.520 & 1.399 \\
& 4 & 5.993 & 7.858 & 5.227 & 7.484 & 1.775 \\
& 5 & 8.906 & 6.938 & 9.985 & 6.634 & 1.930 \\
& 6 & $9.551^{\mathrm{ab}}$ & $8.276^{\mathrm{b}}$ & $13.296^{\mathrm{a}}$ & $7.385^{\mathrm{b}}$ & 1.962 \\
& 5.894 & 7.300 & 8.989 & 7.089 & 2.256 \\
\hline
\end{tabular}

${ }^{\mathrm{a}, \mathrm{b}}$ Means within a row without common superscripts are different at $P<0.05$. 
Plasma BHBA is a measure of rumen epithelial metabolic activity and indicates conversion of rumen butyrate to $\beta$-hydroxybutyrate as it passes the rumen wall (Lane et al., 2000). In addition, Weigand et al. (1975) reported that 26 to $33 \%$ of butyrate absorbed by rumen papillae was converted to BHBA. However, this work was conducted in mature ruminants and may not represent rumen epithelial metabolism in the young calf. Heat processing appeared to decrease plasma BHBA in the current study, indicating that epithelial metabolic activity was decreased in calves receiving RC or SFC starter but increased in calves fed WC or DRC starter. However, plasma BHBA was measured on peripheral blood samples, and thus reported values also include any BHBA converted from butyrate and acetate in the liver. In addition, changes between rumen butyrate and plasma BHBA and their relationship to rumen epithelial metabolic activity have not been fully established. Therefore, decreased plasma BHBA values may be a measure of increased rumen epithelial butyrate metabolism in RC and SFC calves, subsequently decreasing available butyrate for conversion to BHBA.

\section{CONCLUSIONS}

The type of processed corn included in calf starters appears to affect intake, feed efficiency, growth, blood VFA concentrations, and rumen parameters in ruminally developing calves. Starter consumption was enhanced when starter contained WC or DRC; however, the increased intake had little positive influence on BW gain, structural growth, rumen development, or blood and rumen parameters. Rumen development, blood VFA concentrations, and ruminal propionate production were enhanced by incorporation of SFC into the calf starter, but intake, feed efficiency, and growth were negatively influenced. Conversely, calves consuming starter containing RC had similar BW gains, feed efficiency, and rumen development but increased structural growth and ruminal butyrate production when compared with some of the other 3 treatments, despite lower starter intake. The results observed in RC calves indicate an increased ability to convert ingested nutrients into growth and prepare the calf's rumen for weaning.

\section{ACKNOWLEDGMENT}

This research was a component of NC-1119, Management Systems to Improve the Economic and Environmental Sustainability of Dairy Enterprises.

\section{REFERENCES}

Abdelgadir, I. E. O., and J. L. Morrill. 1995. Effect of processing sorghum grain on dairy calf performance. J. Dairy Sci. 78:2040-2046.
Aldrich, J. M., L. D. Muller, G. A. Varga, and L. C. Griel, Jr. 1993. Nonstructural carbohydrate and protein effects on rumen fermentation, nutrient flow, and performance of dairy cows. J. Dairy Sci. 76:1091-1105.

Association of Official Analytical Chemists (AOAC). 1990. Official Methods of Analysis. 15th ed. AOAC, Arlington, VA.

Beharka, A. A., T. G. Nagaraja, J. L. Morrill, G. A. Kennedy, and R. D. Klemm. 1998. Effects of form of the diet on anatomical, microbial, and fermentative development of the rumen of neonatal calves. J. Dairy Sci. 81:1946-1955.

Blaxter, K. L. 1967. The Energy Metabolism of Ruminants. Rev. ed. Hutchinson and Co., Ltd., London.

Broderick, G. A., and J. H. Kang. 1980. Automated simultaneous determination of ammonia and total amino acids in ruminal fluid and in vitro media. J. Dairy Sci. 63:64-75.

Bull, L. S., L. J. Bush, J. D. Friend, B. Harris, Jr., and E. W. Jones. 1965. Incidence of ruminal parakeratosis in calves fed different rations and its relation to volatile fatty acid absorption. J. Dairy Sci. 48:1459-1466.

Chen, K. H., J. T. Huber, C. B. Theurer, R. S. Swingle, J. Simas, S. C. Chan, Z. Wu, and J. L. Sullivan. 1994. Effect of steam flaking of corn and sorghum grains on performance of lactating cows. J. Dairy Sci. 77:1038-1043.

Crocker, L. M., E. J. DePeters, J. G. Fadel, H. Perez-Monti, S. J. Taylor, J. A. Wyckoff, and R. A. Zinn. 1998. Influence of processed corn grain in diets of dairy cows on digestion of nutrients and milk composition. J. Dairy Sci. 81:2394-2407.

Dubois, M., K. A. Gilles, J. K. Hamilton, P. A. Rebers, and F. Smith. 1956. Colorimetric method for determination of sugars and related substances. Anal. Chem. 28:350-356.

Harrison, H. N., R. G. Warner, E. G. Sander, and J. K. Loosli. 1960. Changes in the tissue and volume of the stomachs of calves following the removal of dry feed or consumption of inert bulk. J. Dairy Sci. 43:1301-1312.

Heinrichs, A. J., C. M. Jones, L. R. VanRoekel, and M. A. Fowler. 2003. CalfTrack: A system of dairy calf workforce management, training, and evaluation and health evaluation. J. Dairy Sci. 86(Suppl. 1):115.

Holm, J., I. Bjorck, A. Drews, and N. G. Asp. 1986. A rapid method for the analysis of starch. Starch die starke 7:224-226.

Huntington, G. B. 1997. Starch utilization by ruminants: From basics to the bunk. J. Anim. Sci. 75:852-867.

Joy, M. T., E. J. DePeters, J. G. Fadel, and R. A. Zinn. 1997. Effects of corn processing on the site and extent of digestion in lactating cows. J. Dairy Sci. 80:2087-2097.

Krishnamoorthy, U., T. V. Muscato, C. J. Sniffen, and P. J. Van Soest. 1982. Nitrogen fractions in selected feedstuffs. J. Dairy Sci. 65:217-225.

Lane, M. A., R. L. Baldwin, and B. W. Jesse. 2000. Sheep rumen metabolic development in response to age and dietary treatments. J. Anim. Sci. 78:1990-1996.

Larson, L. L., F. G. Owens, J. L. Albright, R. D. Appleman, R. C. Lamb, and L. D. Muller. 1977. Guidelines toward more uniformity in measuring and reporting calf experimental data. J. Dairy Sci. 60:989-991.

Lesmeister, K. E., P. R. Tozer, and A. J. Heinrichs. 2004. Development and analysis of a rumen tissue sampling procedure. J. Dairy Sci. 87:1336-1344.

McBeath, D. G., W. J. Penhale, and E. F. Logan. 1971. An examination of the influence of husbandry on the plasma immunoglobulin level of the newborn calf, using a rapid refractometer test for assessing immunoglobulin content. Vet. Rec. 88:266-270.

Murphy, T. A., F. L. Fluharty, and S. C. Loerch. 1994. The influence of intake level and corn processing on digestibility and ruminal metabolism in steers fed all-concentrate diets. J. Anim. Sci. $72: 1608-1615$.

National Research Council (NRC). 2001. Nutrient Requirements of Dairy Cattle. 7th rev. ed. Natl. Acad. Sci., Washington, DC.

Naylor, J. M., and D. S. Kronfeld. 1977. Refractometry as a measure of the immunoglobulin status of the newborn dairy calf: Comparison with the zinc sulfate turbidity test and single radial immunodiffusion. Am. J. Vet. Res. 38:1331-1334. 
Owens, F. N., D. S. Secrist, W. J. Hill, and D. R. Gill. 1997. The effect of grain source and grain processing on performance of feedlot cattle: A review. J. Anim. Sci. 75:868-879.

Quigley, J. D., III, Z. P. Smith, and R. N. Heitmann. 1991. Changes in plasma volatile fatty acids in response to weaning and feed intake in young calves. J. Dairy Sci. 74:258-263.

Reis, R. B., and D. K. Combs. 2000. Effects of corn processing and supplemental hay on rumen environment and lactation performance of dairy cows grazing grass-legume pasture. J. Dairy Sci. 83:2529-2538.

SAS. 1999. SAS/STAT User's Guide, Version 8.01 ed. SAS Inst., Inc., Cary, NC.

Schuh, J. D., J. O. A. Lima, W. H. Hale, and B. Theurer. 1970. Steamprocessed flaked grains versus steam-rolled grains for dairy calves. J. Dairy Sci. 53:475-479.

Tamate, H., A. D. McGilliard, N. L. Jacobson, and R. Getty. 1962. Effect of various dietaries on the anatomical development of the stomach in the calf. J. Dairy Sci. 45:408-420.
Theurer, C. B. 1986. Grain processing effects on starch utilization by ruminants. J. Anim. Sci. 63:1649-1662.

Theurer, C. B., J. T. Huber, A. Delgado-Elorduy, and R. Wanderley. 1999. Invited Review: Summary of steam-flaking corn or sorghum grain for lactating dairy cows. J. Dairy Sci. 82:1950-1959.

Trei, J., W. H. Hale, and B. Theurer. 1970. Effect of grain processing on in vitro gas production. J. Anim. Sci. 30:825-831.

Vazquez-Anon, M., A. J. Heinrichs, J. M. Aldrich, and G. A. Varga. 1993. Postweaning age effects on rumen fermentation end-products and digesta kinetics in calves weaned at 5 weeks of age. J. Dairy Sci. 76:2742-2748.

Weigand, E., J. W. Young, and A. D. McGilliard. 1975. Volatile fatty acid metabolism by rumen mucosa from cattle fed hay or grain. J. Dairy Sci. 58:1294-1300.

Yang, C. M. J., and G. A. Varga. 1989. Effect of three concentrate feeding frequencies on rumen protozoa, rumen digesta kinetics, and milk yield in dairy cows. J. Dairy Sci. 72:950-957. 